\title{
Foreign Direct Investment Impact on Economic Indicators of the Baltic Countries
}

\author{
Aida Barkauskaite 1 , Violeta Naraskeviciute ${ }^{2}$ \\ ${ }^{1,2}$ Kaunas University of Technology
}

\begin{abstract}
The foreign direct investment movement is becoming increasingly important nowadays. Various studies are conducted to determine the influence of foreign direct investments on certain countries. That is why it is important and useful to evaluate and compare how foreign direct investments affect the economic indicators of the Baltic countries - countries having similar economies. Methods used in the analysis are: logical comparative and generalization methods, systematic literature analysis and methods of mathematical statistics. The results have showed that foreign direct investments have positive influence on economies through gross domestic product and labour productivity growth in all Baltic countries, though foreign direct investments do not influence the unemployment rate in all Baltic countries.
\end{abstract}

Keywords - Baltic countries, economic indicators, foreign direct investment.

\section{INTRODUCTION}

Foreign direct investment can be identified as one of the most effective tools helping to improve country's economic growth. Countries seek to attract as high foreign direct investment flows as possible because of their various benefits to economies. Foreign direct investment (FDI) and its impact are widely considered in the scientific literature. Rupliene \& Garsviene (2008), Kuliaviene \& Solnyskiniene (2014), Sandalcilar \& Altiner (2012), Ekanayake \& Ledgerwood (2010), Nosheen (2013) and Moraru (2013) analysed the FDI and gross domestic product (GDP) relationship. All above-mentioned authors' studies showed a positive FDI influence on the country's GDP. FDI could also have a positive impact on host country's labour productivity, unemployment rate, diffusion of technologies, human capital formation and international trade integration (Moyo, 2013; Zenasni, Benhabib 2013; Mucuk \& Demirsel, 2013; Laskiene \& Pekarskiene, 2011 and Erdogan, 2011). Foreign direct investment is a significant factor in many national economies and particularly important to small and little known countries in the world, such as the Baltic countries. Therefore, the aim of this paper is to determine foreign direct investment impact on the Baltic countries' economies. The object is foreign direct investment in the Baltic countries. To reach the aim of the study, the following tasks are set: to examine the theoretical foreign direct investment aspects; to analyse foreign direct investment volumes in the Baltic countries; to perform the foreign direct investment impact analysis on economic indicators of the Baltic countries.

The research period for the analysis of FDI impact on the Baltic countries' economies is 2000-2012. But because of data limitations, the analysis of FDI impact on unemployment in different economic sectors of Lithuania covers only the period of 2008-2012. Data of real GDP and unemployment rate will be used from the EU Statistical Office (Eurostat) database, but the labour productivity will be calculated as real gross domes- tic product size created by one employed person. The data of the number of unemployed residents of different economic sectors and FDI volume will be used from the Lithuanian Official Statistics Portal. The influence of FDI on the Baltic countries' economies (GDP, unemployment rate and labour productivity) is analysed in the study, but there is no examination of the determinants of FDI and the distribution of FDI. The research methods are: systematic literature analysis, logical comparative and generalization analyses, methods of mathematical statistics.

\section{Theoretical Aspects of Foreign Direct InVESTMENT EFFECT}

In literature, several definitions of foreign direct investment could be found. According to the European Commission, FDI (2014) is an international investment within the balance of payment accounts. Direct investment enterprises are those in which a direct investor owns ten or more percent of the ordinary shares or voting rights, or the equivalent. According to the International Monetary Fund, the European Union Statistical Office and Economic Co-operation and Development, FDI is considered to be such an investment that forms long-term economic relations and interests between the direct investor and the direct investment enterprise (Valentinavicius, 2010). The World Bank defines FDI as net inflows of investment, which acquired the long-term management interest (10 percent or more of the voting rights) in an enterprise operating in a country different from that of the investor (World Bank, 2014).

Most of the world countries seek to attract foreign direct investments, because usually these investments increase the capital in those countries that are unable to raise funds for major projects themselves. FDI also helps create new jobs, reduce the unemployment rate; wages paid by international firms are often higher than those by domestic companies, as well as the workforce and the quality of work become better (Pilinkiene, 2008). According to Moraru (2013), FDI has a positive influence not only on GDP, but also on the economic growth of the country, improving overall productivity and more efficient use of resources. FDI contributes to the increase of employment over the business development and further development. Kuliaviene \& Solnyskiniene (2014) state that FDI is often considered being one of the most important factors of economic stimulus. It is important to emphasise that in order to get all the benefits from foreign investment, the country should have a favourable business environment, because it stimulates not only domestic but also foreign investments. A favourable business environment contributes to the innovation, skills and competitive business environment (Kurtishi-Kastrati, 2013). Imoughele \& Ismaila (2014) also emphasise that governments should consciously improve 
the business environment in order to have a positive influence of FDI on the country's economic growth.

The positive impact of FDI is not only on the country's GDP growth. Studies by Laskiene \& Pekarskiene (2011) have shown that FDI has a positive effect on the investment of host country's labour productivity. FDI flows have a strong impact on labour productivity growth, but the growth of productivity is not the same in different areas of economic activity. According to Axarloglou \& Pournarakis (2007), FDI impact on the labour market is relatively weak. These results are due to different effects of FDI in various industries, some sectors have a positive impact on the labour market, while in other industries FDI effect on the labour market is negative. Javorcik (2013) states that jobs created by FDI are considered good jobs for both: the employee and the country. Higher wages to employees are paid by foreign companies than by local firms (at least in developing countries). In addition, foreign employers tend to provide more training opportunities to employees. Jobs created by FDI are also useful for the general increase in labour productivity, which is due to increased competition for local businesses. According to Lipsey $\&$ Sjoholm (2005), foreign-owned firms or establishments are usually larger on average than domestic ones, and this even applies to developed countries. Erdogan (2011) argues that foreign capital companies contribute to productivity growth and also to domestic enterprises. The analysis by Melo \& Quinn (2015) has shown that successful attractiveness of FDI can help reduce the amount of corruption in the country but not in all cases. They have revealed that FDI attracted by seeking access to large oil deposits does not lead to reduction of corruption in the country.

FDI has a positive impact on the construction of new factories, management skills and stimulates growth of FDI in the host country (Moyo, 2013). FDI also contributes to the diffusion of technology, human capital formation, international trade integration, job creation, and increases business development (Zenasni, Benhabib, 2013).

Mucuk and Demirsel (2013) studied the impact of FDI on the unemployment rate in seven developing countries; their studies revealed that the causal relationship between FDI and the level of unemployment occurred only in the long run. According to the studies by these authors, most often foreign investors come to the country and purchase or associate with a company already in existence, so FDI usually causes an adverse effect on the unemployment rate in the country. Only a new company's construction form of investment helps create new jobs, thereby contributing to a decrease in the level of unemployment in the country. It should be emphasised that according to the study by Kokko (2006), FDI impact on developing countries is likely to be similar as the effect in developed countries, but possibly in smaller size and of less importance.

Although FDI can bring various benefits to the country, different conditions need to be implemented so that the investment would not have a negative impact on domestic producers. As one of the negative aspects of FDI, unfair competition can be identified. For foreign investors, conferred special privileges may disturb the internal market and thereby undermine local busi- nesses. Special privileges to foreign investors not only distort competition, but also the country has to get the funds for the subsidies, and they achieve it by increasing taxes to the population (Langviniene, Vengrauskas, Zitkiene, 2004). Antwi et al. (2013) in their study revealed that FDI could bring a negative impact on domestic producers. This negative impact on FDI occurs when local producers lose their position in the market, because foreign investors become a monopoly in the market. It indirectly starts to affect local manufacturers, who must try to survive in the market. According to Zemguliene and Zaleskyte (2006), foreign companies may displace local businesses, increasing the concentration of firms in the sector to obtain economic benefits and move earned capital out of the country, in which their investments are performed. Scholar Ozturk (2007) in his study revealed that FDI could have a negative impact on the country's economic growth. In some countries, FDI negatively affects the country's economic growth, while in other countries FDI does not affect or make an insignificant impact on the country's economic growth. GuechHeang and Moolio (2013) argue that FDI impact on economic growth also depends on institutional factors of the host country. Figure 1 summarises the positive and negative effects of FDI.

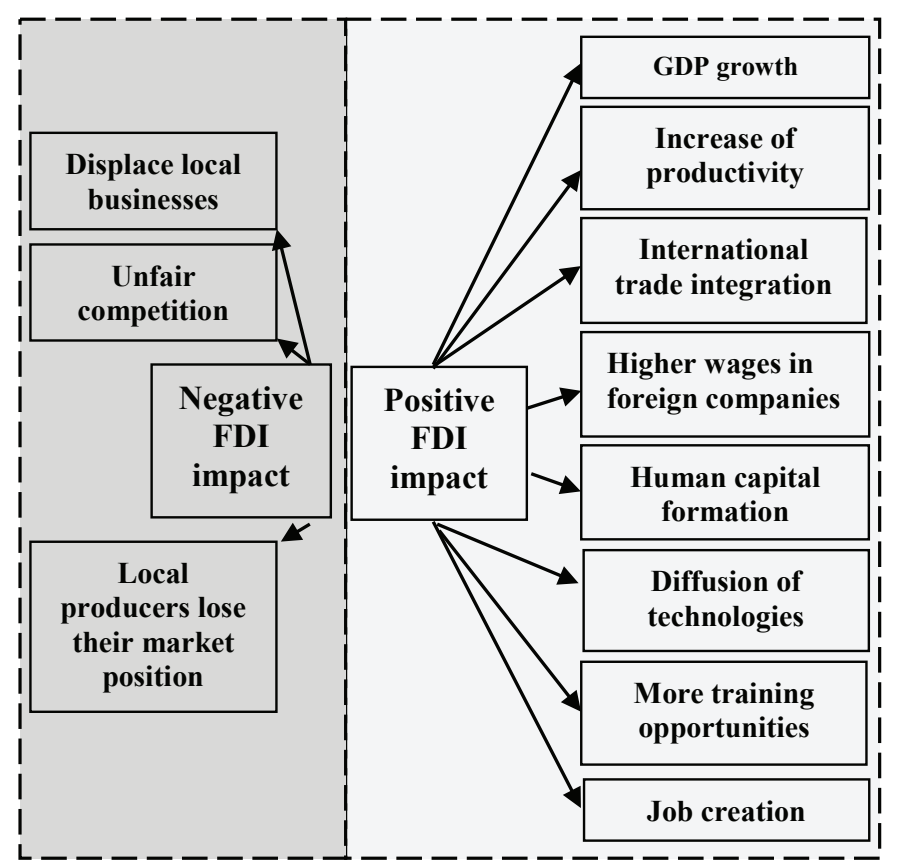

Fig. 1. Positive and negative FDI impact (structured by the authors according to Sandalcilar \& Altiner (2012), Laskiene \& Pekarsniene (2011), Zenasni, Benhabib (2013), Moyo (2013), Antwi, E. Mills, G. Mills and Zhao (2013), Zemguliene \& Zaleskyte (2006), Langviniene, Vengrauskas, Zitkiene, 2004)).

It must be emphasised that while FDI can bring many benefits to the country, the countries adopting foreign investments should consider the potential negative impact of these investments, try properly to orientate these investments and get all the benefits from them. To sum up, FDI can bring many more benefits to the country than harm it - that is why countries seek to attract as more FDI flows as possible. 


\section{Foreign Direct Investment Volumes in Baltic Countries}

Global Opportunity Index ranks 98 countries of the world and focuses on the main determinants of FDI. The index considers not only country's economic situation, but regulates barriers, facilitates doing business, regulates quality and rule of law. By the 2013 Global Opportunity Index ranking, Estonia from the Baltic countries was ranked 11th, Latvia - 24th and Lithuania - 26th (Global Opportunity Index, 2013). Out of 28 European Union member states, according to the Global Opportunity Index rankings, only five EU countries had higher score than Estonia. Thus, it can be said that determinants of FDI in Estonia are very good and Estonia should attract great volumes of FDI.

One of the rankings also related to foreign direct investment is "Doing Business" (Doing Business, 2014). This rating reflects conditions of pursuing business in each country and economies are ranked on their advantage in doing business. Out of 189 ranking countries, by the 2013 "Doing Business" ranking, Lithuania was ranked 17th, Estonia - 22nd and Latvia - 24th. If foreign investors are planning to start their business on the development of a new company, this ratio should be particularly important for them. Figure 2 presents FDI volumes in the Baltic countries during the sudy period of 2000-2012.

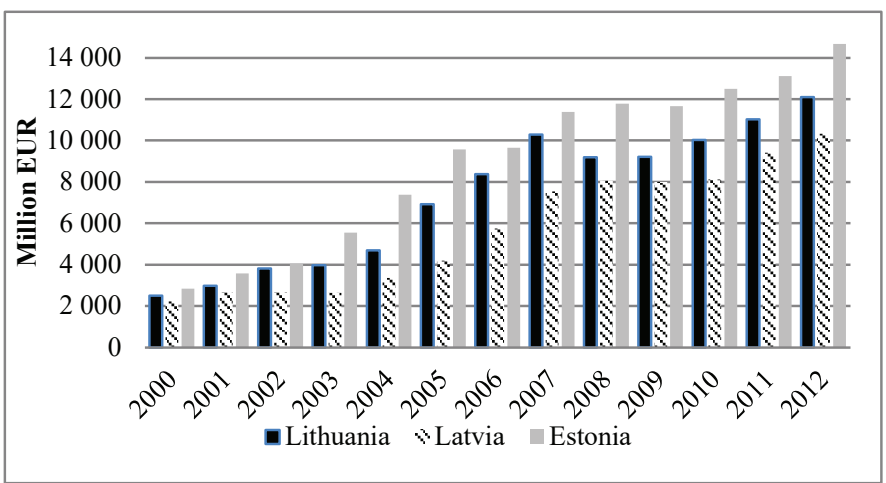

Fig. 2. Foreign direct investment volumes in the Baltic countries in 2000-2012 (structured by Eurostat data).

During the entire study period of 2000-2012, most FDI stocks were attracted by Estonia. FDI stocks in Estonia had been growing within the entire study period, except 2009 - when FDI stocks decreased by 105 million EUR. This decrease of FDI in Estonia in 2009 could be attributed to the economic crisis, for which foreign investors reduced their investments in Estonia. During the whole study period of 2000-2012, by attracted FDI stocks Lithuania was the second from the Baltic countries. Lithuanian FDI stocks had also been growing during the study period, except 2008 - when FDI stocks in Lithuania reduced by $10.62 \%$ or 1092 million EUR compared to the level of 2007 . Although the economic crisis in Lithuania started only in the late 2008, but the decrease in FDI might be associated with the uncertain economic situation around the world, causing foreign investors to reduce their investments in Lithuania. FDI stocks in Latvia decreased in 2002, 2003 and 2009, Latvia attracted the lowest volume of FDI in the Baltic countries during the entire study period.

\section{Foreign Direct InVestment Impact on} ECONOMIC INDICATORS OF THE BALTIC COUNTRIES

In order to determine FDI impact on the Baltic countries' economies, according to the studies by Moraru (2013), Sandalcilar and Altiner (2012), Kuliaviene and Solnyskiniene (2014) as well as Laskiene and Pekarkiene (2011), the indicators have been identified, which are affected by the FDI and are measurable: GDP, labour productivity (LP) and unemployment rate (UR). It is known that these economic indicators are also affected by other factors, but the present study only investigates the influence of FDI. FDI valuation model is illustrated in Fig. 3.

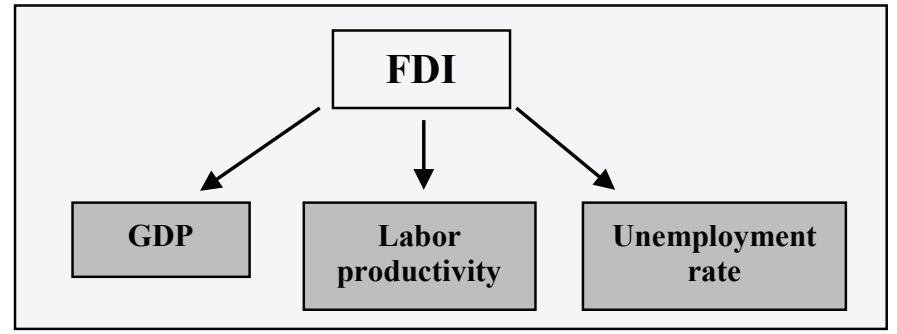

Fig. 3. FDI evaluation model (structured by the authors).

All the data in the analysis were used from the EU Statistical Office database (Eurostat), but the labour productivity in the model could be seen as real gross domestic product size created by a single person. Theoretical models could be defined as $\mathrm{GDI}=f(\mathrm{FDI}), \mathrm{LP}=f(\mathrm{FDI})$ and $\mathrm{UR}=f(\mathrm{FDI})$. Figure 4 illustrates GDP changes in the Baltic countries during 2000-2012.

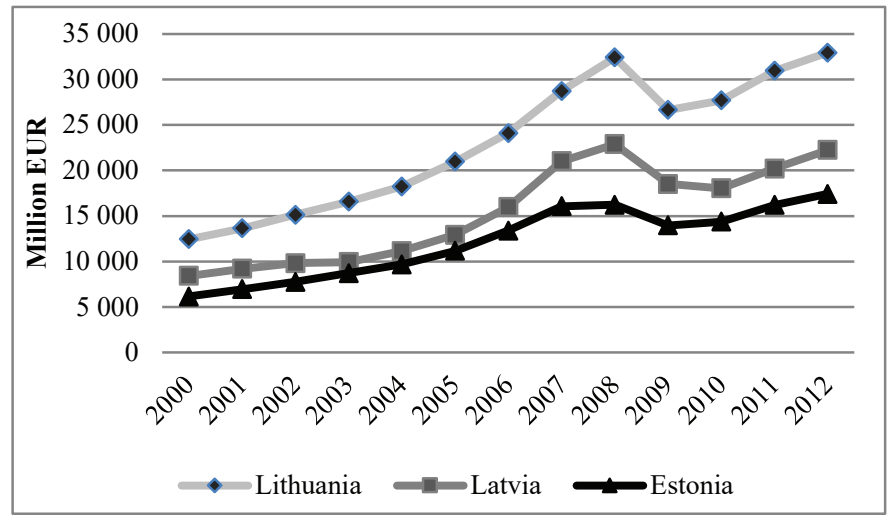

Fig. 4. Gross domestic product volumes in the Baltic countries in 2000-2012 (structured by Eurostat data).

During the study period, the highest GDP volumes in the Baltic countries were created in Lithuania. Analysing (GDP) variations, in the period of 2000-2008 it had a tendency to rise in all the Baltic countries. In 2009 the economic crisis affected the Baltic countries' economies and GDP volumes decreased in all of them by 14-19\%compared to the level of 2008. In 2010 Lithuania and Estonia managed to recover from the crisis and their size of GDP grew by 3 to 4\%. In 2010 Latvia was in a bad economic situation and its GDP volumes declined by $2.6 \%$. Between 2011 and 2012, GDP had a tendency to grow in all the Baltic countries. Comparing GDP and FDI variations, similar 
trends can be seen. Figure 5 presents labour productivity alterations during the study period in the Baltic countries.

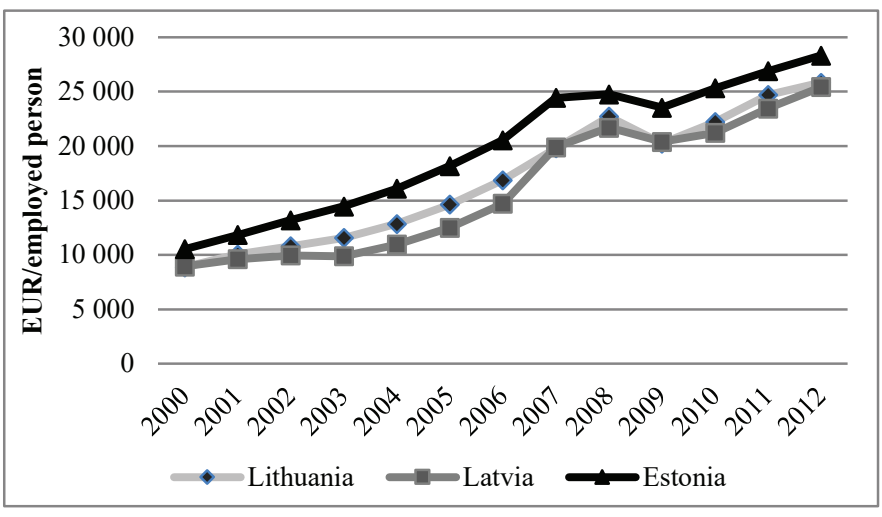

Fig. 5. Labour productivity in the Baltic countries in 2000-2012 (calculated by the authors using Eurostat data).

Labour productivity in the study period varied following similar tendencies as the volume of GDP; however, in 2003 labour productivity decreased in Latvia, while GDP volumes in the same year grew. In Lithuania and Estonia, labour productivity was growing during the period of 2000-2008. In 2009 labour productivity decreased in all the Baltic countries by $5-11 \%$ due to the economic crisis. Though Estonia had the lowest volumes of GDP in the study period, its labour productivity was the highest in the Baltic countries. Although in 2009 GDP volumes in the Baltic countries decreased significantly (by 14-19\%), because of drop in the employed population, the labour productivity indicator decreased less than GDP volumes (felt by 5-11\%.). In recent years, labour productivity has started to grow in all the Baltic countries by $4-11 \%$ every year. Figure 6 shows the unemployment rate in all the Baltic countries during the period of 2000-2012.

In the period of 2000-2003, the highest unemployment rates in the Baltic countries were in Lithuania, while between 2004 and 2012 the highest unemployment rates were in Latvia. In the period of 2001-2007, the unemployment rate had a tendency to decrease in all the Baltic countries, but the economic crisis also affected this indicator and between 2008 and 2010 it increased by $12-13.5 \%$ compared to the level of 2007 . Although the unemployment rate had been decreasing in the Baltic countries in the period of 2011-2012, it did not reach the pre-crisis level. In literature, it is claimed that FDI creates new job places, which should reduce the level of unemployment in the country, but comparing FDI and unemployment rate dynamics in all the Baltic countries there is no clear correlation between these variable changes.

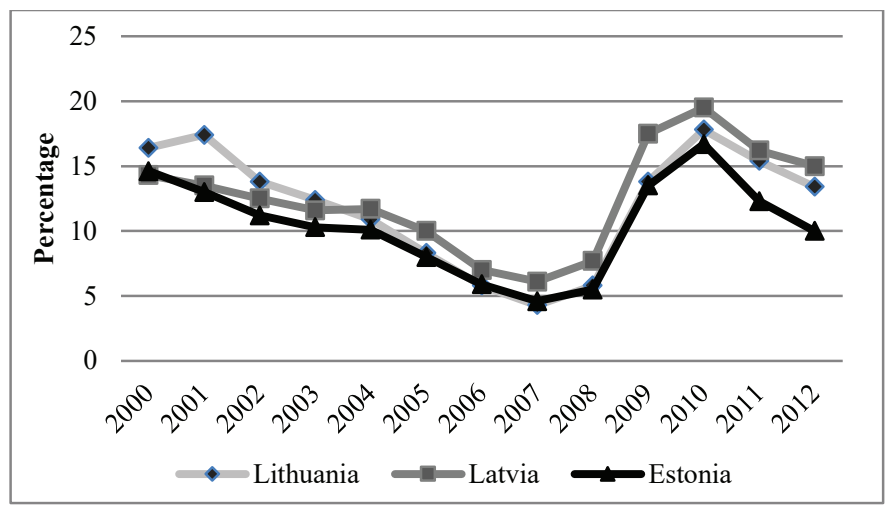

Fig. 6. Unemployment rate in the Baltic countries in 2000-2012 (structured by Eurostat data).

In order to determine the FDI impact on the Baltic countries' economies, strength of the relationship between FDI and selected economic indicators was tested using a correlation analysis. The significance of the results was checked using Student's t-test. Calculated " $t$ " value should be higher than the established critical " $t$ " value from statistical tables (" $t$ " observed $>$ " $t$ " critical, established " $t$ " critical =1.782). The data used in the research were retrieved from the EU Statistical Office database (Eurostat) and covered the period of 2000-2012. The results are summarised in Table I.

TABLE I

Results of Correlation and Its Significance between FDI and Economic Indicators in the Baltic Countries

\begin{tabular}{|l|c|c|c|c|c|c|}
\hline \multirow{2}{*}{ Country } & \multicolumn{2}{|c|}{ GDP } & \multicolumn{2}{c|}{ Labour productivity } & \multicolumn{2}{c|}{ Unemployment rate } \\
\cline { 2 - 7 } & Correlation coefficient & $\boldsymbol{t}_{\text {observed }}$ & Correlation coefficient & $\boldsymbol{t}_{\text {observed }}$ & \multirow{2}{*}{ Correlation coefficient } & \multirow{2}{*}{$\boldsymbol{t}_{\text {observed }}$} \\
\hline Latvia & 0.961032 & 11.53016 & 0.996495 & 39.51023 & 0.204704 & 0.693613 \\
\hline Lithuania & 0.972584 & 13.87095 & 0.974548 & 14.41806 & -0.274350 & -0.946223 \\
\hline Estonia & 0.972342 & 13.80745 & 0.987616 & 20.87768 & -0.222892 & -0.758327 \\
\hline
\end{tabular}

The calculated correlation coefficients show that GDP and labour productivity significantly correlate with FDI, the correlation coefficient in all the Baltic countries is more than 0.9 , which proves a strong positive correlation between the mentioned variables. The relationship of these indicators is direct (the coefficients are positive, so the FDI, GDP and labour productivity move in the same direction, i.e., increase or decrease together) and strong.
However FDI has no relationship with the unemployment rate in all the Baltic countries, the calculated " $t$ " is less than " $\mathrm{t}$ " critical value (" $t$ " observed $<$ " $t$ " critical) in all the countries under consideration. It can be stated that between FDI and the unemployment rate in all the Baltic countries a linear correlation was not found because of potentially different FDI impact on unemployment in different economic sectors or because of the FDI form (if foreign investors start to build new companies 
the unemployment rate should decline, but if investors start to purchase or merge with companies it could even increase the unemployment rate in the country).

A significant linear relationship was found between FDI and GDI as well as between FDI and labour productivity. An example of linear regression using statistical data in case of Lithuania is shown in Figs. 7 and 8. Linear regression models were obtained using the least square method.

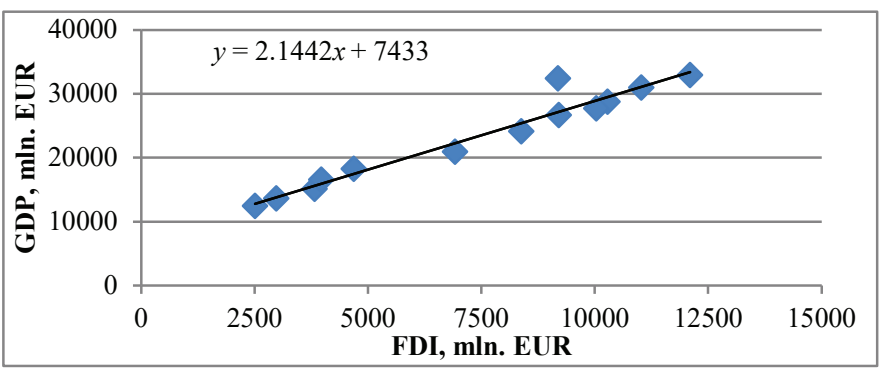

Fig. 7. FDI and GDP linear regression model in Lithuania (structured by Eurostat data).

The theoretical model is GDI $=a * F D I+b$. The model coefficients are shown in Fig. $7(a=2.1442 ; b=7433)$.

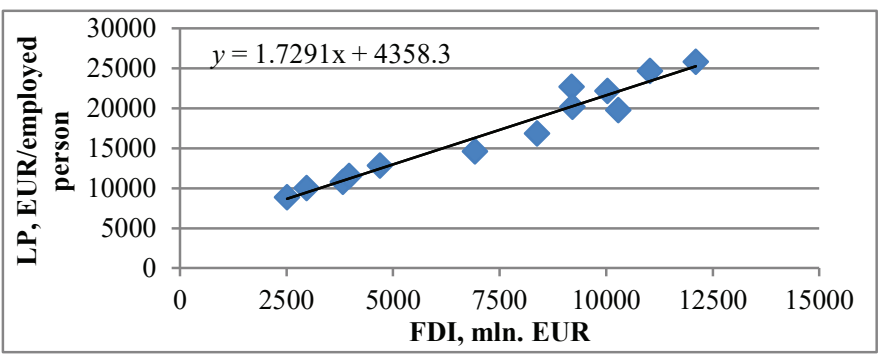

Fig. 8. FDI and labour productivity linear regression model in Lithuania (structured by Eurostat data)
The theoretical model is $L P=a * F D I+b$. The model coefficients are shown in Fig. $8(a=1.7291 ; b=4358.3)$. Despite the high linear correlation coefficients, from Figs. 7 and 8 it is clear that the linear regression model is appropriate for this analysis. The obtained linear regression models for all the Baltic countries are summarised in Table II.

TABLE II

Linear Regression Models for FDI and ECONOMiC INDICATORS IN THE BALTIC COUNTRIES

\begin{tabular}{|l|c|c|}
\hline \multicolumn{1}{|c|}{ Country } & $G D I=a \times F D I+b$ & $L P=a \times F D I+b$. \\
\hline Latvia & $y=1.7644 x+5248.8$ & $y=2.0662 x+4137.8$ \\
\hline Lithuania & $y=2.1442 x+7433$ & $y=1.7291 x+4358.3$ \\
\hline Estonia & $y=0.9665 x+3416,7$ & $y=1.5272 x+6021.9$ \\
\hline
\end{tabular}

After the calculations of linear regression model coefficients, it was found that FDI made lower influence for GDI in Estonia (slope coefficient $a=0.9665$ ), but in Lithuania this FDI impact was higher (slope coefficient $a=2.1442$ ), because "a" value of the model in Lithuania was approximately more than twice higher compared to Estonia. The greatest influence of FDI on labour productivity in the Baltic countries was determined in Latvia (slope coefficient $a=2.0662$ ), while the lowest impact was found in Estonia (slope coefficient $a=1.5272$ ).

To determine whether the FDI had a different impact on the unemployment in different economic sectors, the case of Lithuania was examined. Data on the number of employed by economic sectors were given only after the year 2008 that is why the present study covered the period of 2008-2012. Data for this analysis were obtained from the Lithuanian Official Statistics Portal. Analysing the influence of FDI on the unemployment in individual economic sectors, the dependencies between FDI and employed residents were calculated. Correlation analysis results are given in Table III.

TABLE III

Results of Correlation and Its Significance between FDI and Residents Employed in Different Economic Sectors of Lithuania

\begin{tabular}{|c|c|c|c|c|c|}
\hline \multirow{2}{*}{ Economic sector } & \multicolumn{2}{|c|}{ Residents employed } & \multirow{2}{*}{ Economic sector } & \multicolumn{2}{|c|}{ Residents employed } \\
\hline & $\begin{array}{l}\text { Correlation } \\
\text { coefficient }\end{array}$ & $t_{\text {observed }}$ & & $\begin{array}{l}\text { Correlation } \\
\text { coefficient }\end{array}$ & $t_{\text {observed }}$ \\
\hline Agriculture, forestry and fishing & -0.578123 & -1.227207 & Information and communication & 0.812252 & 2.411873 \\
\hline Mining and quarrying & -0.936766 & -4.636373 & Real estate transactions & 0.626118 & 1.390829 \\
\hline Manufacturing & -0.804227 & -2.343781 & Administrative and support activities & -0.577675 & -1.225780 \\
\hline $\begin{array}{l}\text { Electricity, gas, steam supply and air } \\
\text { conditioning }\end{array}$ & 0.063938 & 0.110972 & Education & 0.830973 & 2.587195 \\
\hline $\begin{array}{l}\text { Water supply, wastewater treatment, waste } \\
\text { management and remediation }\end{array}$ & -0.561393 & -1.174988 & $\begin{array}{l}\text { Professional, scientific and technical } \\
\text { activity }\end{array}$ & 0.926716 & 4.271634 \\
\hline Construction & -0.046589 & -0.080782 & $\begin{array}{l}\text { Arts, entertainment and recreation } \\
\text { activity }\end{array}$ & 0.066201 & 0.114915 \\
\hline $\begin{array}{l}\text { Wholesale and retail trade; motor vehicles } \\
\text { and motorcycles repair }\end{array}$ & -0.591916 & -1.271996 & People's health care and social work & -0.441114 & -0.851336 \\
\hline Transportation and storage & 0.297819 & 0.540358 & Other service activity & 0.529869 & 1.082164 \\
\hline Accommodation and food service activity & 0.836473 & 2.643786 & Other economic sectors & 0.247216 & 0.441906 \\
\hline Financial and insurance activity & -0.601368 & -1.303673 & & & \\
\hline
\end{tabular}


Established " $t$ " critical value for result analysis is 2.132. As it can be seen from Table III, in mining and quarrying; manufacturing economic sectors there is a negative correlation between FDI and residents employed. Between FDI and residents employed in mining and quarrying sectors and in manufacturing sector strong negative correlations exist. The negative correlation means that FDI has a negative impact on the residents employed and causes an increase in the unemployment rate. If FDI stocks in these economic sectors increase, the number of employed decreases. Such influence may occur for new technology takeover from foreign countries. New technologies provide an opportunity to reduce the number of necessary staff and because of that the number of employed is decreasing. On the one hand, this provides a positive benefit to the company; it can reduce its expenses; on the other hand, the flow of FDI in particular economic sectors makes the number of employed decline and leads to an increase in the unemployment rate.

In accommodation and food service activity; information and communication; education; professional, scientific and technical activity a positive linear relationship was found between FDI and residents employed. Only in professional, scientific and technical economic activity, a very strong positive correlation between FDI and the number of employed was found, while in the other mentioned sectors strong positive correlations were found. The positive correlation means that the increase of FDI causes the growth of the residents employed in the mentioned sectors. An increase in the number of employed persons leads to a decrease in the unemployment rate in the country.

In other economic sectors, the correlations between FDI and the number of employed were not found, because the calculated " $t$ " was less than " $t$ " critical value (" $t$ " observed $<$ " $t$ " critical). These results confirmed that the impact of FDI on the number of employed in different economic sectors, or on unemployment rate, differs, that is why calculating relationship between FDI and unemployment rate in all countries the linear correlations could not be found in all the Baltic countries.

Summarising it can be said that FDI has a positive influence on all the Baltic countries' economies through GDP and labour productivity growth. The linear correlation between FDI and unemployment rate was not found due to different FDI impact on the number of residents employed in different economic sectors.

\section{Conclusion}

The following main benefits of FDI can be identified: gross domestic product growth, labour productivity growth, job creation, which contributes to a decrease in the unemployment rate, the takeover of technology and skills from foreign countries. Foreign direct investment can also cause negative consequences, such as unfair competition between foreign and domestic corporations, loss of market position by local producers and displacement of local business. It is important to emphasise that FDI can bring more benefits to the country than damage it, but each country adopting foreign investments must be able to properly direct them, because otherwise FDI can cause a negative impact on the country's economy.
Estonia was one of the Baltic countries that managed to attract the greatest volume of FDI stocks during the entire study period of 2000-2012. FDI stocks in Estonia grew during the period of 2000-2012, except 2009 - when FDI stocks decreased by 105 million EUR due to the economic crisis. During the study period of 2000-2012, Latvia attracted the lowest FDI volumes in the Baltic countries. The economic crisis affected FDI volumes of all the Baltic countries, but the greatest effect was experienced by Lithuania. The Lithuanian FDI stocks decreased by $10.62 \%$ in 2008; in Estonia and Latvia FDI stocks decreased in 2009, but by less than $1 \%$ in both countries.

The FDI impact analysis showed that FDI had a positive influence on the Baltic countries' economies, because the strong relationship between the FDI and GDP was found, as well as between FDI and labour productivity in all the Baltic countries. Coefficients of linear regression models showed that FDI influence differed in all the Baltic countries. FDI made the greatest influence on the Lithuania GDP, while the highest impact on labour productivity was found in Latvia. However, FDI did not influence the unemployment rate in all the Baltic countries. In order to determine why FDI had no impact on the unemployment rate of the Baltic countries, the Lithuanian case was analysed in detail. It showed that FDI in some economic sectors had a positive influence on the number of employed; the established linear relationships were significant, while in other sectors the FDI impact on the number of employed was negative and in some economic sectors FDI did not influence the number of employed.

It was found that FDI had a positive impact on two relevant economic indicators of all the Baltic countries, suggesting that both the countries' entrepreneurs and governments should make efforts to increase Baltic countries' attractiveness to foreign investors. This could be done improving the business environment, promoting business companies to attract foreign investors, improving the countries' infrastructure, providing privileges to foreign investors and finding other ways, but first of all these actions should be supported by governments.

\section{REFERENCES}

Antwi S., Mills. E. F. E. A., Mills G. A., Zhao X. (2013). Impact of Foreign Direct Investment on Economic Growth: Empirical Evidence from Ghana. International Journal of Academic Research in Accounting, Finance and Management Sciences, 3(1), 18-25.

Axarloglou K., Pournarakis M. (2007). Do All Foreign Direct Investment Inflows Benefit the Local Economy? The World Economy, 424-445. http:// dx.doi.org/10.1111/j.1467-9701.2006.00824.x

Doing Business (2014). Doing Business Economy Rankings. World Bank Group. Retrieved Sep. 18, 2014, from http://www.doingbusiness.org/rankings

Ekanayake E. M., Ledgerwood J. R. (2010). How does Foreign Direct Investment Affect Growth in Developing Countries? An Empirical Investigation. The International Journal of Business and Finance Research, 4(3), 43-53.

Erdogan A. I. (2011). Foreign Direct Investment and Productivity Spillovers: Evidence from Turkey. Journal of Applied Finance \& Banking, 1(4), 185-199.

European Commission FDI (2014). Eurostat. Retrieved Sep. 15, 2014, from http://epp.eurostat.ec.europa.eu/statistics_explained/index.php/Glossary:Foreign direct investment (FDI)

Eurostat (2014). Eürostat Database. Retrieved Sep. 18, 2014, from http://ec.europa.eu/eurostat/data/database

Global Opportunity Index (2013). Retrieved Sep. 18, 2014, from http://www. globalopportunityindex.org/opportunity.taf?page=rankings

GuechHeang L., Moolio P. (2013). The Relationship between Gross Domestic Product and Foreign Direct Investment: The Case of Cambodia. KASBIT Business Journal, 6, 87-99.

Imoughele L. E., Ismaila M. (2014). The Nature of Foreign Direct Investment and Its Impact on Sustainable Economic Growth in Nigeria. Journal of Economics and Development Studies, 2(1), 201-232. 
Javorcik B. (2013). Does FDI Bring Good Jobs to Host Countries? Background Paper for the World Development Report 2013, University of Oxford and CEPR, 1-22.

Kokko A. (2006). The Home Country Effects of FDI In Developed Economies. EIJS Working Paper Series, The European Institute of Japanese Studies, No. 225. Retrieved Dec. 27, 2014, from https://ideas.repec.org/p/hhs/eijswp/0225.html

Kuliaviene A., Solnyskiniene J. (2014). The Evaluation of the Impact of Foreign Direct Investment on Lithuanian Economy Using LAG-Analysis. Economics and Management, 19(1), 16-24. http://dx.doi.org/10.5755/j01.em.19.1.5597

Kurtishi-Kastrati S. (2013). The Effects of Foreign Direct Investments for Host Country's Economy. European Journal of Interdisciplinary Studies, 5(1), 26-38.

Langviniene N., Vengrauskas P. V., Zitkiene R. (2004). Tarptautinis verslas 2 knyga. Kaunas: Technologija.

Laskiene D., Pekarskiene I. (2011). Tiesioginiu uzsienio investiciju poveikis investicijas priimancios salies darbo produktyvumui. Ekonomika ir vady ba, 16, 207-213.

Lipsey R. E., Sjoholm F. (2005). Host Country Impacts Of Inward FDI: Why Such Different Answers? Institute for International Economics, chapter 2,p. 23-44. Retrieved Dec. 27, 2014, from https://ideas.repec.org/p/hhs/ eijswp/0192.html

Melo L., Quinn M. A. (2015). Oil, Foreign Direct Investment and Corruption. The International Journal of Business and Finance Research, 9(1), 33-49.

Moyo T. (2013). The Impact of Foreign Direct Investment on Economic Growth: The Case of Zimbabwe (2009-2012). International Journal of Economics, Finance and Management Sciences, 1(6), 323-329. http://dx.doi. org/10.11648/j.ijefm.20130106.19

Moraru C. (2013). Foreign direct investment and economic growth in Romania. Theoretical and Applied Economics, 20(5), 125-134.

Mucuk M., Demirsel M. T. (2013). The Effect of Foreign Direct Investments on Unemployment: Evidence from Panel Data for Seven Developing Countries. Journal of Business, Economics \& Finance, 2(3), 53-66.

Nosheen M. (2013). Impact of Foreign Direct Investment on Gross Domestic Product. World Applied Sciences Journal, 24(10), 1358-1361.

Official Statistics Portal (2013). Statistics Lithuania. Retrieved Oct. 12, 2014 from http://osp.stat.gov.lt/en/home

Ozturk I. (2007). Foreign Direct Investment - Growth Nexus: a Review of the Recent Literature. International Journal of Applied Econometrics and Quantitative Studies, 4(2), 79-98.

Pilinkiene V. (2008). Tarptautiniai ekonominiai santykiai. Kaunas: Technologija

Rupliene D., Garsviene L. (2008). Tiesioginiu uzsienio investiciju itaka salies ekonominiam augimui. Ekonomika ir vadyba: aktualijos ir perspektyvos 3(12), 262-270.

Sandalcilar A. R., Altiner A. (2012). Foreign Direct Investment and Gross Domestic Product: An Application on ECO Region (1995-2011). International Journal of Business and Social Science, 3(22), 189-198.

The World Bank (2014). Foreign direct investment, net inflows. World Bank Group. Retrieved Sep. 15, 2014, from http://data.worldbank.org/indicator/ BX.KLT.DINV.CD.WD

Valentinavicius S. (2010). Investiciju valdymas. Teoriniai ir praktiniai aspektai. Vilnius: Vilniaus universiteto leidykla.

Zemguliene J., Zaleskyte J. (2006). Foreign Direct Investment in Lithuania Sectors of Investment as Determinant of Growth. Organizaciju vadyba: sisteminiai tyrimai, 38, 195-203.

Zenasni S., Benhabib A. (2013). The Determinants of Foreign Direct Investment and Their Impact on Growth: Panel Data Analysis for AMU Countries. International Journal of Innovation and Applied Studies, 2(3), 300-313.

Aida Barkauskaite, graduated from Kaunas University of Technology, Faculty of Economics and Business, in 2014, acquired Bachelor's degree in Economics. Since 2014, she has been studying at the master study programme "Finance". Fields of scientific interest: foreign direct investments impact and its determinants analysis; interest rate analysis; shadow economy and its impact on the country's economy analysis; analysis of different scientific activities.

Address: K. Donelaičio g. 20, Kaunas, LT-44239, Lithuania.

Telephone number: +37065 470957 .

E-mail: aidabarkauskaite33@gmail.com

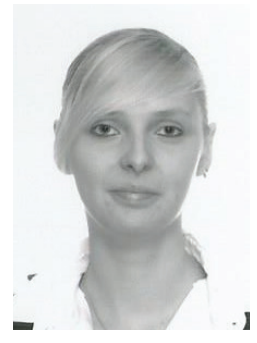

Violeta Naraskeviciute, graduated from Kaunas Polytechnic Institute in 1979, the acquired specialisation is an Engineer - Economist.

Work experience: from 1979 to 1982 , she worked as an Engineer, Scientific Associate; since 1982 she has been working as a Lecturer at Kaunas University of Technology. She is also an advisor for companies on matters of corporate finance.

Fields of scientific interest: public finance, business

finance, companies' financial analysis, business basics and finance.

Address: K. Donelaičio g. 20, Kaunas, LT-44239, Lithuania.

Telephone number: +37068673664.

E-mail: violeta.naraskeviciute@ktu.lt 